\title{
To Survive Ravensbrück: Considerations on Museum Pedagogy and the Passing on of Holocaust Remembrance
}

\author{
Katrine Tinning*
}

\begin{abstract}
How can museums pass on the remembrances of the survivors of Holocaust in ways that engage visitors? This article looks at the ways museums remember the Holocaust by focusing on an exhibition entitled To Survive - Voices from Ravensbrück at the museum of cultural history, Kulturen, in Lund, Sweden. The exhibition centres on a unique collection of small objects secretly and illegally created by women in the Ravensbrück concentration camp as acts of resistance against the inhuman conditions in the camp. Exhibits on the Holocaust represent a particular tradition of museum pedagogy, associated with the imperative of 'never again', often read as an attempt to evoke empathy and responsibility for other human beings. In line with this tradition, the educational aim of To Survive is to encourage the viewers, to be moved to a greater sense of responsibility. The article provides a detailed description of the exhibit, discusses the choice of the museum to tone down the dark aspects of the story, and looks into how the exhibition realizes various appeals to the visitor, but also how it makes some voices mute. As such this article contributes to the ongoing museological discussions of the complexities of putting so-called difficult knowledge on display.
\end{abstract}

Key Words: Museum Pedagogy, Visual Pedagogy, Memory Studies, Holocaust Studies, Difficult Knowledge, Ethical responsibility, Visitor involvement.

\section{From the concentration camp to the museum space.}

This article explores the permanent exhibit entitled To Survive - Voices from Ravensbrückshown at Kulturen in Lund, Sweden. ${ }^{1}$ The exhibit displays a unique collection of small objects secretly and illegally created by women in the Ravensbrück concentration camp. The small objects were collected by a professor of the Polish language at Lund University, Zygmunt Lakocinski (1905-1987), who during the war had been engaged in documenting the Nazis' crimes.

In April 1945, white buses from the Swedish and Danish Red Cross arrived at the concentration camp of Ravensbrück situated about ninety kilometres north of Berlin. The convoy of buses, equipped with medical supplies, were part of a joint Swedish-Danish relief effort led by the Swedish count Folke Bernadotte, who, after negotiations with Heinrich Himmler, head of the concentration camps, had got permission to rescue survivors from Ravensbrück and other camps, and bring them to Sweden for medical treatment and rehabilitation.

Ravensbrück was the only concentration camp intended primarily for women. The camp was designed for hard labour, and the women worked in the fields, loading railway wagons, and digging mass graves. They also worked in the factories located in and just outside the camp, making various products including clothes for the German soldiers. Most of the women in the camp suffered from or died from malnutrition, maltreatment, medical experiments or diseases. In 1944 a gas chamber was built, and close to 6000 women were murdered there. Between 1939 and 1945, the camp imprisoned more than 130,000 women and children; no more than 15.000 to 30.000 of them survived.

The white buses picked up 7000 prisoners from Ravensbrück, and some of the women 
were brought to Malmö in Sweden. Here Lakocinski got to meet them. He had been asked by the Polish Legation in Stockholm, Sweden, to act as an interpreter for the Polish survivors who arrived at Malmö and to collect their testimonies ${ }^{2}$. Lakocinski himself was a Pole. In the 1930s he had studied in Krakow, and met Carola von Gegerfelt, who came from Sweden to study there. Lakocinski's professor had asked him to show von Gegerfelt the city, and so he did - and they fell in love. When von Gegerfelt went back, Lakocinski went to visit her in Lund, Sweden, and he decided to stay. They married in 1935, and had three children.

A large number of the people Lakocinski spoke with were Polish. He not only gathered testimonies of life in the camp, but also collected a number of small items made by the women themselves or given to them by 'camp-mates' from Ravensbrück. The items had been made illegally and kept in secret as acts of resistance against the inhuman conditions in the camp. Often, the women had put themselves at risk 'organizing' stuff for creating the items and hiding them in their dresses or shoes, in holes in mattresses, under floorboards, or on the roof. In Sweden, the authorities - afraid of diseases - wanted to burn not only the women's clothes, but also the items. Lakocinski, with the help of the ex-prisoners and his contacts, succeeded in saving some of them. ${ }^{3}$

When, in 2004, Lakocinski's children decided to donate to Kulturen the collection of artifacts from Ravensbrück, which they had inherited in 1987 after the death of their father, it was on the condition that the museum would create an exhibition of the objects. ${ }^{4}$ The permanent exhibition entitled To Survive - Voices from Ravensbrück opened on January the $27^{\text {th }} 2005$ - 60 years after the end of World War II, and the year Lakocinsky would have turned 100 years old. ${ }^{5}$ It shows the entire collection of 200 objects, together with excerpts from interviews with survivors.

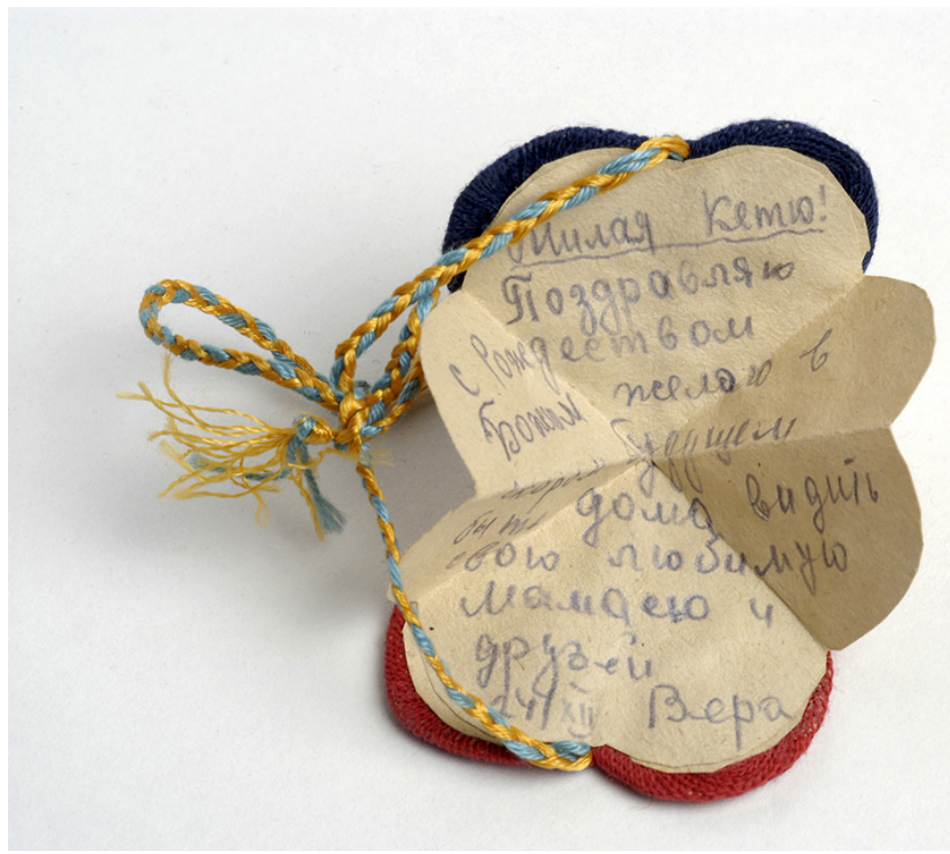

Image 1: Card made by a prisoner in Ravensbrück Concentration Camp, and shown in the exhibition entitled To Survive - Voices from Ravensbrück. (C) 2014, Viveca Ohlsson, Kulturen. Used with permission.

\section{Difficult Knowledge}

Attempts to express voices of survivors in the museum, as in To Survive, is interesting to museum pedagogy. Now, about 70 years after the collapse of the Nazi Regime and the end 
of World War II, we are losing the voices of first person perspectives as the survivors of the traumas of Second World War are passing away. This puts a pressure on museum pedagogy regarding how to continue to make such voices present. In the museum field there has been a growing interest in discussing the complexities of putting 'difficult knowledge', like surviving the Holocaust, on display. ${ }^{6}$ Sharon Macdonald calls attention to how 'difficult heritage' may be perceived as troublesome "because it threatens to break through into the present in disruptive ways' (Macdonald 2009:1). Eva Silvén and Anders Björklund in their Difficult Matters: Objects that Disturb and Affect observe how objects connected to a difficult past may affect visitors - and upset them (Silvén and Björklund 2006). This article attempts to contribute to conversations on such 'difficult knowledge' in museum exhibitions. It provides a detailed description of the exhibit, shows how the various appeals of the museum to visitors have been realized in the exhibit, and discusses what kinds of voices have been muted or marginalized. In discussing the educational aims of the museum, the method of personalizing the history of surviving, and relating the exhibition to the difficulties of bearing witness to a traumatic past, the article explores how hard it is to balance a bright and a dark history in presenting Holocaust remembrance. The exhibition, while small in scale, typifies how a country which was not directly involved in the war, thinks and continues to think about itself as humanitarian - and how it struggles with the question of teaching humanitarianism, and ethical responsibility.

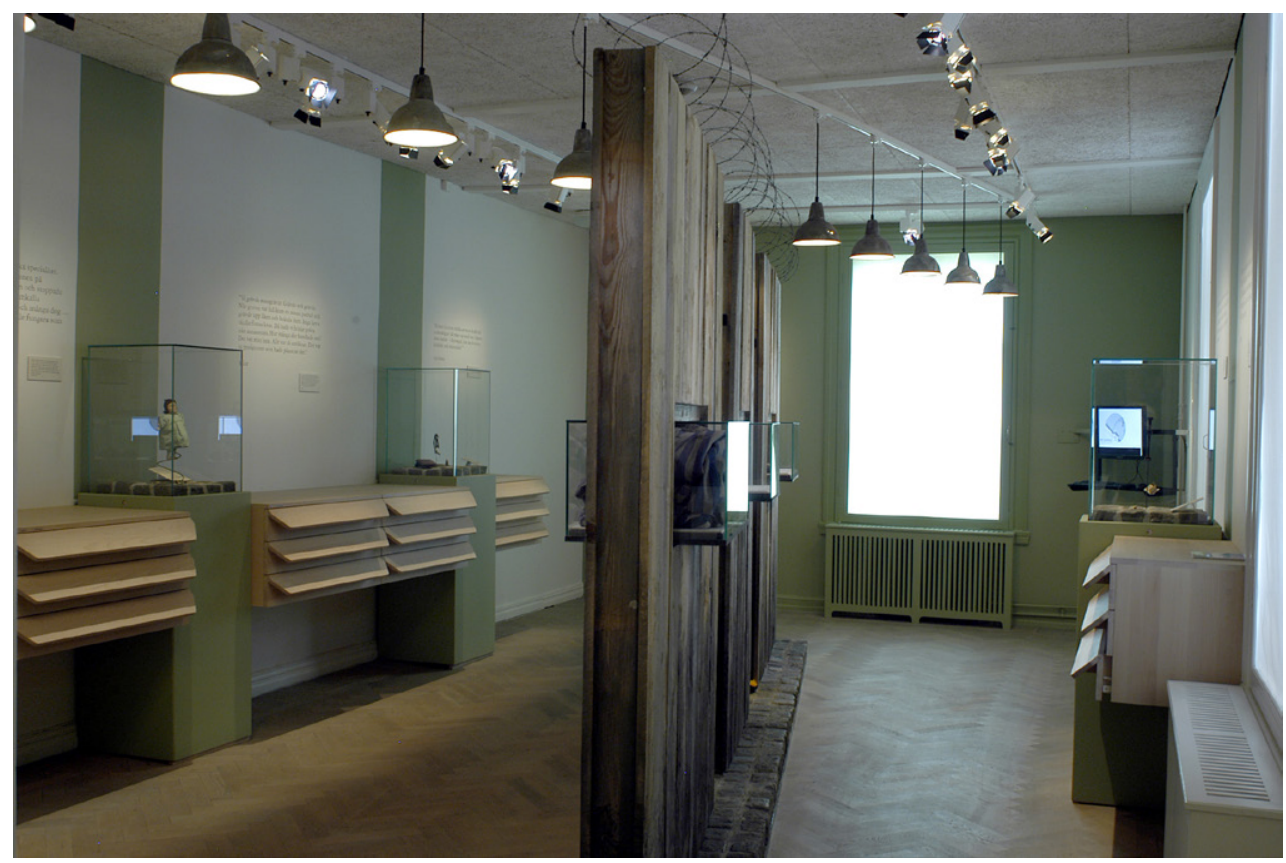

Image 2: The exhibition entitled To Survive - Voices from Ravensbrück. (c) 2014, Viveca Ohlsson, Kulturen. Used with permission.

\section{A closer look at the exhibition}

The exhibition is on the second floor of the museum building. The first thing one encounters is a series of three large introductory panels with black and white photos. The panels stretch from ceiling to floor and introduce (in Swedish only) three themes. The first panel, 'Falling in Love', tells the love story of Lakocinski, and the story of his anti-Nazi work. The second panel, 'Ravensbrück', shows statistics from the camp, and includes quotations from survivors. The third panel, 'Arrival in Sweden', describes the rescue action, Lakocinski's work as an interpreter, and his efforts to preserve the objects. A last panel gives a summary in English. 
The exhibition itself covers no more than 40 square metres. At the entrance, a sign introduces a 'study room'. The room is in white, dusty green and beige-brown colors, and sparsely furnished: seven chests of drawers made in wood veneer are placed along the long walls on the left and right of the entrance. The entrance is on one of the short walls; on the other short wall at the back of the room is a window covered with a white fabric letting the light in. With only a few traditional display cases made of glass, most of the objects in the exhibition are hidden in the drawers, not immediately visible at a first glance. There are a few short texts, some of them written with black, transparent letters on the walls, and others written on white signs placed in the display cases. There are also only a few images, no audio equipment, and no multi-media features. Organized so as to induce the visitor to walk clockwise around a replica of a barrack wall made in rough wood planks, which runs diagonally through the room, the exhibition is 'linear', but not chronological: aside from the time-frame presented in the introductory panels, references to time are relatively absent in the exhibition (e.g. neither objects nor interviews are dated).

The wall is designed like a collage with two glass panels with black and white photographs of female camp prisoners. Viewing the photographs on the clear glass is like peeping into life in the camp. The panels divide the wall in three parts each with a glass case inserted into it; cases can be viewed from both sides of the wall. The first case contains a prisoner's dress coiled into a ball. The second one displays what is labelled as 'treasures': two small handmade books, a needle with a pearl at the end, a half nutshell, and small flowers, a snowdrop, made of plastic. ${ }^{7}$ The third case displays examples of gifts, among others a little heart shaped card with a handwritten letter on white paper. A quotation from the woman Apolonia ${ }^{8}$ reads:

Mostly we didn't make things for ourselves. We made them for each other, to give away as presents. Just the thought, the knowledge that somebody was thinking about you, made you happy. Somebody is thinking about me!... and at the same time... what a risk she took!.

When entering the room right to the left the first category is 'De-humanisation'. Here is a display case containing a suitcase, and above is a chart hand-painted onto the wall, which shows the symbols used in the camp. ${ }^{9}$ Next to the chart is a text translating the categories into Swedish and English. It is one of the few texts in the exhibition narrated in the museum's voice. The tone is tempered and matter-of-fact:

On arrival in the camp the women were stripped of their identity. The Nazis sorted the prisoners into different groups and marked with numbers and symbols to show what the prisoner was accused of and thus how she should be treated by the guards.

On the right side of the chart a quotation from a woman named Alice reads:

When we got to the hut we had to take off all our clothes and fold them up. Then over to another hut where we were made to get down on our knees. We were shaved all over. Then to the next hut. On with the prisoner's clothes. After an hour we looked like all the others in the camp: no dignity, humiliated, ridiculed.

Next, you stand in front of a series of chests of drawers placed along the wall on the left side of the room. Each chest of drawers is linked to a specific theme, and contains various small objects associated with that theme plus quotations from the women, and/or a brief, curatorial note. The first chest of drawers belongs to the theme 'Dehumanization'. Above it a quotation from Apolonia reads:

There was constantly shouting and yelling. The Nazis wanted to crush us, to take our human dignity from us. The hunger and cold were hard. So was the doubt: 'who am I?' The guards hit us and shoved us all the time. They showed us the chimneystacks and said: 'That's the way you are getting out. No other way.'

The top drawer contains a number of prisoners' signs and numbers. The middle drawer shows a women's civilian clothes with a black cross printed on, and the accompanying quotation from 
Maria tells you that there were not enough prison uniforms, so many prisoners had to wear their ordinary clothes with a cross on. The bottom drawer contains various kinds of clothes. The next chest of drawers holds objects categorized as belonging to «The Camp. Sabotage'. Above it is a quotation from Apolonia:

Each camp had its own medical speciality. In Ravensbrück they cut open the legs of young prisoners, from the knee to the foot, and put in dirty rags to provoke infections. They got a high fever and many died. They selected the ones who were to be guinea pigs at the roll calls.

The top and middle drawers shows various drawings on life in the camp, and letters written by prisoners to their families. When opening the drawer at the very bottom, one finds a pair of brown woollen socks, made by the women working in the industries of Ravensbrück. The accompanying curatorial commentary tells that socks for German soldiers were produced by prisoners in the industries. A quotation from the woman Inger explains this further:

The woman in charge of the knitters was a political prisoner, who had been in prison for many years.... She had found a way to knit socks, which meant that the soldiers got sores on their heels. So the boys did not get further than Stalingrad. They could not manage any more.

In the bottom drawer you will also find a little piece of a broken red lipstick. As it is the case with the socks and the lipstick, the objects on display often have a double meaning, or a new and surprising meaning compared to your previous understanding. The lipstick could save lives, as recalled by the women named Alice: 'When it was selection time, you were chased out of the hut. Those who were unfit for work, were gassed (you would) colour your cheeks red, so that you looked healthy'.

A hand-made doll is displayed in a large display case next to the chest of drawers named 'The Camp/Sabotage'. A short curatorial commentary tells you that 'dolls were made to the children in the camp. Some prisoners tell how dolls were also used for smuggling messages...'. Next to the case are two chests of drawers. In the first one are artefacts classified as 'Articles for every day use': needles, scissors, thread, a spoon, knives, brushes, and glasses. The next chest of drawers is named 'Memorabilia'. Next to it is a display case with a miniature doll, a set of keys and a wallet, and next to it, is the last chest of drawers, which also shows objects categorized as 'Memorabilia'. The display case contains a miniature doll (a tiny figure of a women churning butter), a set of keys, and a red wallet. The chests of drawers contain various items made out of materials the women got hold of in the industries. For example, you will find recipes written on the back of various kinds of wrapping, home-made note books, necklaces made of pearls and corns, flags made of pieces of cloth, tiny dolls and animals in textiles in various colours, books with covers made of straw, a ring of some plastic material, a pocket knife, coins, and a miniature painting on a wooden block of a naked couple kissing each other. ${ }^{10}$ The quotations alongside the artefacts tell how re-collection helped the women to escape mentally, and maintain an idea of existence, and a life with others, beyond the dehumanizing conditions in the camp. Recalling recipes and poems was a way of imagining another reality than the camp life, for example the woman Inger says: 'Busying myself with things made me feel like a human being. It wasn't all just slaps and blows and shouting'.

On the green wall at the back wall of the room, nest to the window, there is a quotation from Apolonia:

We weren't allowed to meet in big groups, but people formed small groups, often under the leadership of some teacher or scholar who held lectures. We hungered for something else... hunger for something for the mind. I'll never forget the lecture on astronomy. We gathered with a professor and looked at the stars together. In the cold winter the sky was beautiful and the stars shone bright. Before we went to bed she showed us the stars and pointed out the different constellations.... It was fantastic.

Moving on to the wall on the right side of the room there is a chest of drawers titled 'Religion. Hunger for Something for the Soul'. Above the chest of drawers is a quotation from Zofia D. 
who explains: 'There comes a time when you don't think it is worth living and you're not afraid. Then a lot of people throw themselves against the electric fence. If you believe in God I think it helps you to survive'. In the top drawer you find rosaries made of strings, yarn, berries, grains, and breadcrumbs. The accompanying quotation from Maria tells you how prayers were strictly forbidden and punished by the guards in the camp. The second drawer presents hand-drawn maps written out of the memory of the women of their home town or country: e.g., a map of France sketched out on a tissue, and an outline of Moscow and its closest districts. In an accompanying text the museum explains:

The Nazis tactic was to break the prisoners physically and mentally. In the camp there were some older women who tried to counter act this. By trying to remember as many details as possible from their previous lives, it was easier to imagine that there would be a time after the camp.

In the bottom drawer there are a number of small calendars, and an excerpt from Apolonia says:

A calendar was worth its weight in gold.... When someone was sick they wanted to check whether that person was in good mental health and they often asked what day it was.... If you weren't able to answer, it could happen that you were sorted out...

Finally, you get to the last two chests of drawers, which show artefacts categorized as 'Treasures and Gifts'. This is the end of the exhibit. Between the two chests of drawers is a display case, containing a large cross, which is made of iron screw bolts, a tiny cross in plastic, and a very small hand-written book with poetry. In the drawers, you find a little hatpin, a necklace, ears of corn, a dried white flower, a rose in red textile, a fork with flowers on the handle, and a mirror. In the accompanying text the museum explains the meaning of the things:

Every personal object became a confirmation that you really were someone. A group of women from France had developed a strategy to prevent the Germans from beating their spirit. Every Saturday they would 'embellish themselves'. During the week, they had to focus on the problem of finding something to adorn themselves with. It could be an ear of corn to stick in the buttonhole, a string to tie up the hair, or a hatpin found somewhere.

\section{Playing down the dark aspects of the story}

The prologue at the entrance of the exhibition is centered on Lakocinski's love story and his work to collect testimonies. Situating Lakocinski as a protagonist, the history is personalized so as to exemplify Swedish humanitarianism as Lakocinski enters the scene as a figure incorporating Swedish ideals. The story of Lakocinski as a central motif in the story of surviving concerns this question of humanitarianism, and connects to the educational vision of the museum to teach lessons on ethical responsibility.

All of the small objects were put on display for the first time in a temporary exhibition at Kulturen between 1998 and 1999. In 2006 the museum opened the permanent exhibit of the objects. The transition from the temporary exhibition to the permanent one illustrates a passage from a dark display to a brighter one, e.g. by making use of light colours, only showing a few photographs, and putting emphasis on surviving. Generally, in communicating the Holocaust, there is a schism in regard to the point of talking about the 'dark heritage'. In relation to the exhibition entitled To Survive, a tension exists in relation to the audience. The Museum identified the target group to be all kinds of people, but especially created the display with school children in mind, and the museum was concerned not to overwhelm the young audience emotionally. ${ }^{11}$

The producer Karin Schönberg ${ }^{12}$ recalls how, in the temporary display, there had been visitors who fainted because of the impact it had on them. ${ }^{13}$ Curator Anita Marcus has described the atmosphere of the 1998 exhibition: 
The room... was quite big and it had a high ceiling. In the middle of the room there were five exhibition cases placed on cobblestones. The objects were displayed on a harsh, dark cloth in the wrapping they originally had had... The room was surrounded with barbed wire. It was rather dark. Only the objects and the quotations on the walls were illuminated by strong lamps. We wanted to evoke a strong emotional impression. ${ }^{14}$

In creating the permanent exhibition, the concept of the exhibit was re-considered in order to play down the emotional impact. A central argument of project leader Margareta Alin for a less emotional design was the durability of the exhibit, or as she explained: 'You work in a different way if the exhibition is to be permanent, you can't have aspects that are too sensational, or emotionally overwhelming. The exhibition will become old too quickly that way' ${ }^{15}$

The museum now specifically wanted to arrange the story not as a 'dark history' of abuse, but as a 'light history' of surviving. The scenography needed to communicate an atmosphere, which would tune the visitor in accordance with this 'brighter' and more hopeful pedagogical approach. The scenography was much more low key, with a relatively brighter lighting, and the general atmosphere of a 'study room' as opposed to a dramatic set (see also Bonnell and Leroux 2005). The walls were coloured white and green in order to allude to light, hope and growth. ${ }^{16}$ Centred on what made people survive Ravensbrück - including the capacity of the survivors to contribute to the making of the display of the story - the exhibition was intended to personify the strength the inmates had to persevere and inspire in visitors the feeling that there is something you can and must do in the face of inhumanity - that you have an ethical responsibility.

Curating the exhibition, the location of the display was considered. To Survive is placed in a building where other exhibitions are on display as well. The museum also contains a large open-air department. The museum presumed that visitors would not come just come to see the exhibition on surviving, which is but a small room in the large museum area. Rather, most visitors, the museum thought, would arrive the open air department or the larger exhibition on the history of Scania, and would not like finding themselves all of a sudden face-to-face with a display of the horrors of the Holocaust. Further, while To Survive was designed to generally meet the needs of all kinds of visitors, the museum created the exhibition specifically with school children in mind. Therefore the exhibition needed to be convenient and acceptable for them and adapted to their needs and capacities. ${ }^{17}$

As a result, the museum made the mise-en-scene of the exhibition appear more neutral and discrete. This also had to do with the assumption of the museum that the objects and stories in themselves are very emotionally charged, and that it would not be necessary to create spectacular scenery in order to make an appeal to visitors to get involved. Schönberg sums up the idea: 'It is a sensitive subject matter, one should not shout it out loud, but let people take the message to their heart little by little'. ${ }^{18}$ The mise-en-scene was created so as to allow for each visitor to individually direct her or his engagement with the exhibition. With no photos immediately visible, and most of the objects hidden in shelves, the aim was to make it possible for the visitor to unpack the exhibition at her or his own pace..$^{19}$

Designing the exhibition, the museum also felt they had to take into consideration the Jewish community in Lund as a central stakeholder. For example, the museum was careful about how they expressed the facts in the information texts. ${ }^{20}$ This illustrates how the Holocaust is often linked to Jewish history and historiography. In case of To Survive, this special attention may seem paradoxical, because out of six women quoted from in the exhibition, only two are described as Jews, two as Catholics, and two are not categorized (Marcus and Forsell 2006: 18-21).

The argument for toning down the dark aspects of the mise-en-scene, and their emotional impact - because the stories and objects themselves were dramatic and forceful - also guided the decision not to use a larger technological apparatus, including moving images, which could 'boost' the visitors' experience. The basic idea was to create an exhibition like a low-tech study room, which should appear as a small quiet room for reflection. ${ }^{21}$ 


\section{Towards Ethical Responsibility}

Exhibits on the Holocaust represent a particular tradition of museum pedagogy associated with the imperative of 'never again', often read as the hope of evoking empathy and responsibility for other human beings. In line with this tradition, the educational aim of To Survive is to encourage such a sensibility in its viewers to the extent that they are moved to a greater sense of responsibility for others. In the preface to the 'Teacher's Guide' - a guide book for school teachers introducing the exhibition, its themes and informants, which was published in 2006 - the authors Maria Marcus and Sara Forsell explain the message, and motivations behind putting the artefacts and testimonies on display:

We do it because it is needed. In Sweden - right now - racism has grown. Islamophobia, antisemitism, homophobia increases. Have we not learned anything from history? Today we are seeing, what was developed then. Do we see what is happening now? (2006:3).

This approach is in line with the introductory text to the web-exhibition ${ }^{22}$, where the museum quotes from the Swedish poem named 'Krilon Själv' by Ervind Johnson:

We may not forget/As long as we live, we must remind the others /About what has happened. / I see how humans forget. / I see how the peoples forget. /Perhaps we forgotten much in ten years / And in twenty, I dare say, / We are on the way to forgetting everything /But we may not forget! / Remember! /N'oubliez pas! / Glem det ikke! / Kom ihåg! (Johnson 1943).

Incorporating the autobiographical excerpts and the artefacts into a narrative centred on surviving as a human being, the educational message of the museum rests on the assumption that daring to go up against cruelty and indifferences is a risk worth taking, and fundamental to ethical responsibility. In the 'Teacher Guide', Marcus \& Forsell write: 'Many of the women thought that they had nothing to lose. Perhaps one could bring it to a head and say that exactly by risking one's life, one re-conquered it' (Marcus and Forsell 2006: 15). The aim of the museum, then, is to use the story of surviving as a story of humanitarian crisis from which visitors can learn; rather than to limit the story to a Jewish story or to a story about the Holocaust, the story of surviving says something about a wider humanitarian problem, the problem of inhumanity. This way, the problems of the past, which the exhibition deals with, are presented as permeating the present, and demanding visitors' attention to both historical and contemporary existence.

The 'Teacher's Guide' suggests a pedagogical activity named 'Ethical Workshop', which centres on four questions about ethical responsibility, and one's own role, which the museum finds relevant to discuss in relation to the exhibit (Marcus and Forsell 2006: 16-17). The first question, 'What is courage?', appeals to considerations as to what it means to respond and act, even when to do so is seen as being dangerous and frightening. The second question, 'How are human beings classified and graded?' is about categorization, and its possible violent implications. The third question, 'What does it take to survive?', concerns what it means to stay alive as a human being. The fourth question, 'What could make me a murderer?', deals with inhumanity, and the most extreme example of failure of one's ability to care for the other.

The questions of the 'Ethical Workshop' can be connected to the educational aim of the museum, i.e. to create empathy and evoke responsibility. The 'Ethical Workshop' implicitly suggests that students will acquire knowledge both about surviving the Holocaust and strategies for thinking and acting through engagement with open-ended questions, which involve both their ability to understand and share the feelings of others, and their capacity to consider their own role.

While the museum provides no fixed answers, the four questions direct attention to certain areas which the museum finds relevant in connection to the exhibit, and therefore they implicitly express the approach of the museum to ethics. The museum does not relate their ethical approach to any theoretical position. Yet it implicitly bears resemblance to Emmanuel Lévinas' ethics of responsibility, which emphasizes the importance of one's response to other people in a (face-to-face) situation rather than universal standards: i.e., rather than asking 'what is just?', the question is 'how to respond?' (Lévinas 2008, 2009). In accordance with a 
Levinasian position, the museum calls attention to the inter-dependence of persons to oneanother, and how others are vulnerable to one's choices. ${ }^{23}$

The idea that the exhibition can function as an incentive to learn from history about one's ethical responsibility corresponds to the assumption made by Roger I. Simon, who maintains that exhibitions on difficult knowledge, such as the Holocaust, hold the potential of 'informing a citizenry about historically significant events and serving as a stimulus to actions that would guard against the re-occurrence of such violence' (Simon 2011: 198). Following Simon, this leads to a fundamental question to museum pedagogy: 'how to represent the suffering of others so as to provoke sustained attention, concern and corrective action rather than a few days' sensation that is soon forgotten' (Simon 2011: 206).

From this perspective, To Survive can be seen as an educational appeal to its visitors, compelling them to consider its message, and to learn from it. This line of thinking comes close to Simon, when he talks about the 'transitive function' of difficult exhibitions, and how it is grounded in a hope that 'the exhibitions that trace the lives of others who lived and died in times and places other than our own may yet have some force that enjoins our capacities and felt responsibilities' (Simon 2011: 208). It also keys into Silvén and Björklund's suggestion that museums as societal institutions have a moral obligation in '...playing a role in society's emotional crisis management on the basis of the museums' special abilities, such as offering a non-commercial, non-confessional place for reflection on existential matters in a historical and cultural perspective' (Silvén and Björklund 2006: 256). Such a commitment by museums may also entail a moral imperative to function as a zone for collective processes of re-narration of the meaning of ethical responsibility.

The educational aim of the museum to teach ethical responsibility is not made explicit in the exhibition, but it is communicated in the 'Teachers Guide' and the web-exhibition. Still, the museum provides no guides as to how to act responsibly in a contemporary context. Although this may appear as a shortcoming, what Elizabeth Ann Ellsworth ${ }^{24}$ maintains in relation to her analysis of the appeal of the US Holocaust Museum, which aims 'precisely at staging responsibility as an indeterminate, interminable labour of response' (Ellsworth 2002: 25 ) is that, while refusing to ultimately suggest how one should respond, the museum does not leave one 'free'. Rather, it leaves the visitor with a feeling of empathy towards the victims while essentially avowing that 'There is no responsible act that I could perform that would put an end to the Holocaust' (Ellsworth 2002: 24). Similarly, To Survive is staging the history of surviving as a complex drama, which is a scary story, but also a story of heroines and role models for ethical engagement worth imitating.

\section{Biographies of Surviving}

When applying an educational approach focused on the material objects and accounts of the women's life stories, the intention of the museum was to present the history of surviving as something tangible, nearby, and to create a sense of proximity to history in its viewers. The curator Maria Marcus explains that the aim was to show that history is not an abstraction, but about concrete human beings in flesh and blood:

When you look at these artefacts, and read the texts it comes so close to you. You have read that so and so many people died in the concentration camps, but here it is about human beings, not just numbers' 25

The personal life stories put human faces on history. The objects, in many cases objects which are part of our everyday life (e.g. scissors, dolls, pens), while inserted into the 'odd' arrangement of the exhibit, 'speak' to their viewers in an intimate or familiar way, making the connection between our own mundane life and the extraordinary circumstances of the subjects in the exhibition.

The biographical notes in the exhibition represent the women's voices, the first person perspectives. The first names of the women are mentioned in connection to the excerpts and, while in Ravensbrück, women were deprived of their names and were identified publicly only by numbers, in the exhibition, they get their back their names, and identity, in a public space. However, the exhibition never 'fleshes out' the individual women as whole persons. There are 
no references to their last names provided, no pictures of them, and no information, which might help the visitor to get an idea of the women and their personal contexts. The 'Teachers Guide', however, shows photos of the women, and provides biographical information on their life trajectories before and after the Holocaust. Not providing this information in the exhibition but in the Teachers Guide was a way of the museum to guarantee the women some kind of anonymity. ${ }^{26}$ In addition, it can be related to the strategy of the museum to make it possible, in this case for teachers, to measure out the information provided in proportion to the emotional impact of the exhibit on the students. However, you may speculate if the strategy of not providing information on the life courses of the women in the exhibit poses risks of not making visible for the viewer how the trauma of the event and experience of the Holocaust stretches out in time and place.

When offering relatively little information on the individual women, a point could be that the museum personalizes history without individualizing the women and their recollections. In effect, the exhibition expresses the collective, and shared memory of the women, while at the same time showing how women - rather than just numbers - are human beings with distinct voices. In the exhibit the voices from Ravensbrück, in their various tones and styles, turn out to produce a polyphonic choir, or noise, disturbing the quiet atmosphere in the reflection room. Similarly, the unique artefacts appear as connected rather than singled out in the display: the excerpts from interviews, and the informative texts made by the museum explain the meanings of clusters of things, not particular artefacts in themselves.

Drawing attention to surviving not as an anonymous but rather as a personal - yet jointly lived - experience of what it means to cling to life in the camp, the exhibition appeals to viewers' sense of proximity, or relatedness, to other human beings, and feelings of proximity to a history they, too, are part of. On this point, the exhibition - as a transfer point, or a node, between past and present - may have the potential to encourage the viewer's sense of being implicated, and responsible.

As the educational method of the museum is centred on persons, and distinctive objects, rather than general or abstract matters, it has its starting point in pathos in its attempt to appeal to visitors' feelings in order to create engagement. The method of personalizing and sentimentalizing the history of survival permeates the whole design of the exhibition; it even sustains the story of the collection told in the prologue to the exhibition on the panels at the entrance. Here Lakocinski is performing the role of the main character, and, contrary to the women in the exhibition, he is not 'effaced': a picture shows him strolling along hand in hand with his wife. By use of this educational modus operandi the museum performs a gesture of gratitude to Lakocinski and his relatives for donating the collection to Kulturen as well as indicating the dependence of collective memory on personal devotion, and the ability to imagine future needs in order to illuminate the past.

Lakocinski's love story keys into the narrative thread running through the exhibition. Walking clockwise through the room as suggested by the design, and the 'Teachers' Guide', you will at the same time walk a story beginning with a description of the horrible conditions in the camp and ending with chest of drawers showing 'Treasures and Gifts'. The very last drawer at the bottom ties together the narrative yarn by displaying tiny items, which the prisoners gave each other as presents. This closing of the exhibition conveys the importance of hope, faith and love $^{27}$ expressed in the care and generosity of the women and materialized in the objects. By use of this educational method the museum suggests that 'love' is a key term in understanding what it means to survive as a human being, and fundamental to ethical responsibility. Even surviving is characterized very specifically as linked to acts of care and courage. The argument is that making the exhibition, it was of central importance to the museum to create a distinct angle on the material. ${ }^{28}$

It is worth noting here that, since the women are categorized as generalized figures of the 'survivor', the attempt to personalize the history of surviving, ironically, appears also as a way to de-personalize, or stereotype, the past. By making the women play the role of the general 'survivor', and refraining from more 'thick' descriptions of the characters, the unique traits of the particular first person, or eye-witness perspectives tends to evaporate. In relation to the educational aim of the museum to teach ethical responsibility, this is problematic, because from the point of view of Lévinasian ethics of vulnerability (Lévinas 2008, 2009), it is 
attentiveness and response to the specificity of the other human being, and her/his life story, which grounds ethical responsibility.

Linenthal identifies a recent interest in survivors as 'sacred figures', and sees this as part of a larger fascination with mass violence, which reveal a continual state of being troubled by atrocities of the Nazis (Linenthal 2001: XV). ${ }^{29}$ To be sure, To Survive represents another example of being disturbed by the inhumanity of which the Holocaust has become a similitude, but at the same time it is more preoccupied with scrutinizing the question of love and care, than it is absorbed by 'feeding' contemporary attractions to mass violence. The exhibition in this sense represents 'sacred good' as opposed to 'sacred evil'. The mass violence, though touched upon directly or indirectly in the texts, and photos, rather 'peeps in' from the 'holes' or the 'margins' of the stories of creating things and communities, and of collecting practices, which were narrated as acts of care and courage, and which, in the context of the exhibition, signify as operations of ethical responsibility. This general tendency may reflect a contrast in Sweden's historical memory of the war, and specifically of the Holocaust when contrasted, for example, to parallel memory sites in European countries, which were actively complicit in mass murder.

In addition, the exhibition performs specific narratives of the experience of surviving. It shows extracts from interviews with six different women from Ravensbrück. Four of the women had been arrested for being active in a resistance movement, one of them was arrested because her brother participated in a resistance movement, while one women was sent to Ravensbrück because she was Jewish. This means that - out of six - five of the interviewees were connected to the underground movement, and had to wear the special triangle showing they were political prisoners. You may ask if their background influenced the way the women experienced life in the camp life and how they understood the objects, which the museum asked them to explain the meaning of. Would other women have voiced the experiences of Ravensbrück differently? The exhibition, however, does not offer any answers to these questions.

Further, when discussing the representation of the voices of surviving in the exhibition, one may ponder if the exhibition expresses a specific 'female' universe. Not only does the exhibition display the stories of female survivors, and show objects, and practices which have conventionally been interpreted as belonging to some sort of a female world (e.g. knitting, make up), but the exhibition itself was primarily managed, produced and researched by women while the designers were male. ${ }^{30}$

\section{Conclusion}

In creating To Survive the museum made an effort to encourage an empathetic sense of responsibility on the part of the young audience to be active participants in making a better world. In essence, it produced a specific history of surviving Ravensbrück combined with a certain perspective, which appeals to a certain kind of empathy. As a result some traits of the past have been made visible, while others have been erased. Narrating the story of surviving the museum brought into focus Lakocinski and the women as role models, but while Lakocinski is fleshed out as an individual in the exhibition, the women are primarily shown as 'types', even as they are given voices and names. The distinct educational angle of the museum on the material also means that the women and things from Ravensbrück are characterized as symbols, or the very proof of survival. Ultimately, the voices and objects on display appear as emblems of Lakocinski's work, which represents the ethical work that the museum is teaching.

In order not to overwhelm the audience emotionally, the museum chose to focus the story of surviving on hope, love and care. The educational strategy was to make a bright performance, and avoid stirring up visitors' feelings, yet also turning the women into empathetic subjects. The hopeful approach of Kulturen was also grounded in a moral choice centred on the aim of teaching a very specific understanding of ethical responsibility with Swedish humanitarianism as a role model. The figure of Lakocinski incorporates ideals of Swedish care, and help for the victims of the Third Reich. This presentation of public history can be seen as a continuation and addition to an image deeply rooted in Swedish society of the country's neutrality and extensive humanitarian work during Second World War. ${ }^{31}$ Furthermore, the narrative of Lakocinski's action to rescue the small things from being burned by the authorities 
adds to the understanding of ethical work as a responsive practice grounded in a face-to-face meeting, which transgresses prevailing rules.

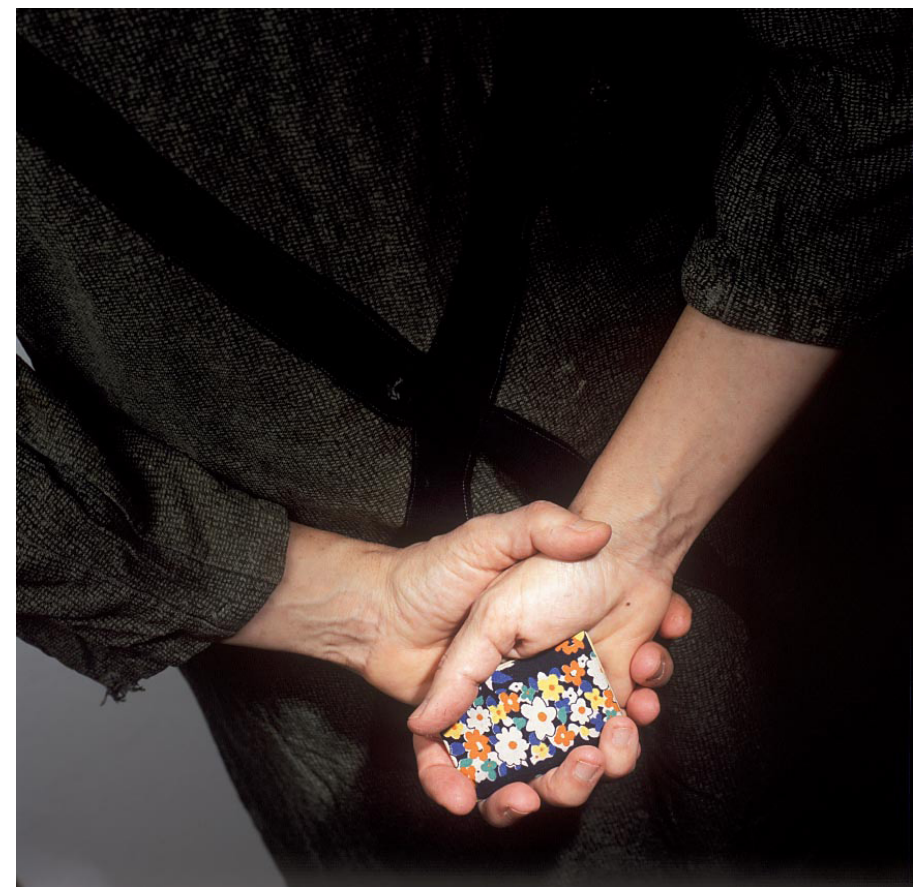

Image 3: Small items were kept in secret. @ 2014, Viveca Oh/sson, Kulturen. Used with permission.

Received 11 August 2015 Finally Approved 10 June 2016

\section{Notes}

1 Kulturen is a museum of cultural history founded in 1892. It is Sweden's (and the world's) second largest open air museum. It also has several permanent exhibitions e.g. on the cultural history of Scania, as well as various temporary exhibitions. It is founded by the Region Scania and the Municipality of Lund.

2 Throughout the year 1945-1946 Lakocinsky was the leader of a working group established in order to collect evidence of the crimes of the Nazis against the Polish People. In order to do so, Lakocinsky and his helpers conducted 500 in-depth interviews with survivors. Also, the working group collected data about the concentration camps, e.g. lists of SS-officials in the camps, catalogues of prisoners and their stays in various camps, and registers of executed persons and persons used in surgical experiments. They also collected material made in the camps, for example, prisoners' letters to each other, their relatives and friends, prisoners' notes on executed co-prisoners, files of persons, chronological descriptions of trends of events, as well as prisoners' poems, and prayer books. They also collected descriptions on the camp prisoners journey to Sweden and their first time there (Rudny, Paul (2015) Polski Instytut Źródlowy w Lund (PIZ). Polska Källinstitutet i Lund. En Presentation av Arkivet, Lund: Lunds Universitets Bibliotek. http://www3.ub.lu.se/ravensbruck/piz-engpresentation.pdf accessed 25 February 2015). 
3 The women had also brought with them original documents, which gave witness to the violence of the Nazis. Lakocinski collected the testimonies, and several of them have been preserved and kept in storage at the University Library in Lund.

4 Schönberg, Karin (2015) Personal conversation with author, Lund, Spring 2015.

5 Some of the objects were put on display by Lakocinski's group in 1966. From 1993 to 1998 some of the objects were shown in the permanent exhibition at Kulturen named 'Lund after 1658'. In 1998 the collection was shown in a temporary exhibition entitled To Survive: Memories from Ravensbrück in connection to a national government sponsored campain to increase the awareness about the Holocaust named The Living History Project. This was an educational operation, and a response to a perceived lack of awareness among young people in Sweden about the events of Second World War, and the Holocaust in particular.

6 For literature dealing with 'difficult knowledge' in museum contexts see Bennett 2005; Silvén \& Björklund 2006; Bonell \& Simon 2007; Macdonald 2009; Cameron \& Kelly 2010; Lehrer, Milton \& Patterson 2011; Simon, Rosenberg \& Eppert 2011; Macdonald 2011; Tinning 2013.

7 While not explained in the exhibition, the 'Teachers Guide' to the exhibition by Marcus and Forsell 2006, explains that women working in the industries got hold of all sorts of materials, for example toothbrush handles, which they used in the fabrication of artefacts.

8 Following up on the interviews made with female survivors from Ravensbrück in connection with the temporary exhibition in 1998, Anita Marcus (who was in charge of research, text and content in relation to the permanent exhibition), did further interviews together with Sara Forsell. In the permanent exhibition excerpts from interviews with six women who had survived Ravensbrück and were still alive in the late 1990s (Maria, Apolonia, Alice, Zofia, Inger, and Anika) are presented. These women represent the voices from Ravensbrück.

9 Arriving at the camp, the women were classified into groups and marked with numbers and symbols. Each prisoner had to wear a triangle, which showed which category they belonged to. About $25 \%$ of the women in Ravensbrück were Polish, and many of them were marked as political prisoners, because they had worked against the Nazis or had been arrested as a substitute for a relative who was member of the resistance movement.

10 The producer of the exhibition, Karin Scönberg, explains that the museum in most cases does not know who created the object (Schönberg, personal communication with author, Lund, Spring 2015).

11 Schönberg, personal communication with author, Lund, Spring 2015.

12 Schönberg, personal communication with author, Lund, Spring 2015.

13 The incident today, given the fairly opaque circumstances surrounding it, appears like a myth told and re-told in the museum.

14 Anita Marcus, quoted from Bonnell and Leroux 2005: 18.

15 MargaretaAlin, quoted from Bonnell and Leroux 2005: 18. Alin here refers to the developers' efforts to grapple with 'difficult history', curatorial attempts, which, as Bonnell and Leroux note, 'are not particularly evident in the exhibition' (Bonnell and Leroux 2005:18).

16 Schönberg, personal communication with author, Lund, Spring 2015.

17 Schönberg, personal communication with author, Lund, Spring 2015. 

Lund: Lunds Universitet, p. 6 (author's translation from Swedish). http://lup.lub.lu.se/ luur/download?func=downloadFile\&recordOId=2335642\&fileOld $=2335645$, accessed 25 February 2015

One cannot ignore how this ending echoes Paulus' letter to the Corinthians: 'Love is patient, love is kind... bears all things, believes all things, hopes all things, endures all things. Love never fails... now faith, hope, love, abide these three; but the greatest of these is love' (E-bible. Paulus' Letter to the Corinthians. http://ebible.org/web/1Cor.htm, accessed 16 February 2015). Paulus' letter to the Corinthians. E-bible).

28 Schönberg, personal communication with author, Lund, Spring 2015.

29 For a discussion on heritage sites, and the fascination with mass violence see also literature on so called 'dark tourism', e.g. Lennon and Foley (2000); Sharpley and Stone (2009).

30 Margareta Alin (Project leader), Karin Schönberg (Producer), Anita Marcus (research, text, content), Anita Marcus \& Sara Forsell (authors of the Teachers Guide), Peter Holm (Design), Björn Hegelund (Cabinet Design).

31 The ambiguous role of Sweden in Second World War (for example, how the country exported iron ore to Nazi Germany, and simultaneously conducted extensive attempts to rescue the Jews) is treated in various publications, see e.g. Bruchfeld and Levine 1998; Linder 2002; Åmark 2011.

\section{References}

Benneth, Jill (2005) Empathic Vision: Affect, Trauma, and Contemporary Art, Stanford: Stanford University Press.

Bonnell, Jennifer \& Leroux, Darryl (2005) Case Studies Toward Re-thinking The Practice of Public History: Case Study of the Exhibition Surviving, Voices from Ravensbrück, Kulturen Museum, Lund, Sweden. Working Paper from the Legacy of Testament Research Project. Unpublished.

Bonnell, Jennifer \& Simon, Roger I. (2007) 'Difficult Exhibitions and Intimate Encounters', Museum and Society 5 (2) 65-85.

Bruchfeld, Stephane \& Levine, Paul (1998) Tell Ye Your Children: A Book About the Holocaust in Europe 1933-1945, Stockholm: Regeringskansliet. 
Cameron, Fiona \& Kelly, Lynda (eds.) (2010) Hot Topics, Public Culture, Museums, Newcastle upon Tyne: Cambridge Scholars Publishing.

Ellsworth, Elizabeth Ann (2002) 'The U.S. Holocaust Museum as a Scene of Pedagogical Address', Symploke 10 (1-2), 13-31.

Johnson, Eyvind (1943) Krilon Själv, Stockholm: Albert Bonniers Förlag.

Lehrer, E., Milton, C., \& Patterson, M., (eds.) (2011) Curating Difficult Knowledge: Violent Pasts in Public Places, New York: Palgrave Macmillan Memory Studies.

Lennon, John and Foley, Malcolm (2000) Dark Tourism: The Attraction of Death and Disaster, London: Continuum.

Lévinas, Emmanuel (2008) Totality and Infinity: An Essay on Exteriority, Pittsburgh, Pennsylvania: Duquesne University Press.

Lévinas, Emmanuel (2009) Otherwise than Being or Beyond Essence, Pittsburgh, Pennsylvania: Duquesne University Press.

Linder, Jan (2002) Andra Värdskriget och Sverige: Historia och Mytbildning, Svensk Militärhistorisk Bibliotek.

Linenthal, Edward T. (2001) Preserving Memory: The Struggle to Create America's Holocaust Museum, New York: Columbia University Press.

Macdonald, Sharon (2009) Difficult Heritage: Negotiating the Nazi Past in Nurenberg and Beyond, London \& New York: Routledge.

Macdonald, Sharon (2013) Memorylands: Heritage and Identity in Europe Today, London \& New York: Routledge.

Marcus, Anita and Forsell, Sara (2006) Att Överleva. Röster från Ravensbrück. En Lärarhandledning (To Survive. Voices from Ravensbrück. A Teachers Guide to the Exhibition), Lund: Kulturen.

Sharpley, Richard and Stone, Philip R. (eds.) (2009) The Darker Side of Travel: The Theory and Practice of Dark Tourism, Bristol, Buffalo, Toronto: Channel View Publications.

Silvén, Eva \& Björklund, Anders (2006) 'Detecting Difficulty' in Eva Silvén and Anders Björklund (eds.) Svåra Saker: Ting och Berättelser som Upprör och Berör, p. 248 264, Stockholm: Nordiska Museets Förlag.

Simon, Roger I. Rosenberg, Sharon \& Eppert, Claudia (2011) 'Introduction: The Pedagogical Encounter of Historical Remembrance', in Roger I. Simon, Sharon Rosenberg and Claudia Eppert (eds.) Between Hope and Despair: Pedagogy and the Remembrance of Historical Trauma, p. 1 - 8, Lanham, Boulder, New York and Oxford: Rowman \& Littlefield Publishers, Inc.

Simon, Roger I. (2011) 'Afterword: The Turn to Pedagogy: A Needed Conversation on the Practice of Curating Difficult Knowledge', in Erica Lehrer, Cynthia Milton and Monica Eileen Patterson (eds.) Curating Difficult Knowledge: Violent Pasts in Public Places, p. 193 - 209, Houndmills, Basingstoke, Hampshire \& New York: Palgrave Macmillan Memory Studies.

Tinning, Katrine (2013) 'Museum Pedagogy and the evocation of Moments of Responsibility', Journal of Nordic Museology, 2 67-96. 
Todd, Sharon (2003) Learning from the Other: Lévinas, Psychoanalysis, and Ethical Possibilities in Education, Albany: State University of New York Press.

Åmark, Klas (2011) Att bo granne med Onskan: Sveriges Förhållande till Nazismen, Nazityskland och Förintelsen, Stockholm: Albert Bonniers Förlag.

*Katrine Tinning is a Ph.D. candidate at the Division for Education, Department of Sociology at Lund University in Sweden. Her doctoral research investigates exhibitions about 'difficult knowledge' from the perspective of pedagogy with a focus on ethics of vulnerability. Katrine has an MA in European Ethnology, and Pedagogy.

Katrine Tinning

PhD Candidate

Lund University

Division for Education, Department of Sociology

Paradisgatan 5, SE-221 00 Lund, Sweden

+46 (0) 462228874

katrine.tinning@soc.lu.se 